\title{
FUTEBOL E NEGÓCIOS
}

Há várias copas do mundo, das várias modalidades. Todos os anos são realizadas diversas copas do mundo, ou simplesmente mundiais, de algum esporte... Copa do mundo disso ou daquilo. Futebol, porém, é o único caso que não precisa explicar: basta dizer Copa do Mundo e, portanto, sabe-se que o tema é futebol. Para ajudar os interessados no tema e seus correlatos, Marco Aurelio Klein Diretor da Federação Paulista de Futebol e do Ministério do Esporte - selecionou cinco obras, considerando desde o neófito em futebol e Copas do Mundo até o iniciado nos problemas, oportunidades, marketing e negócios do chamado nobre esporte bretão.

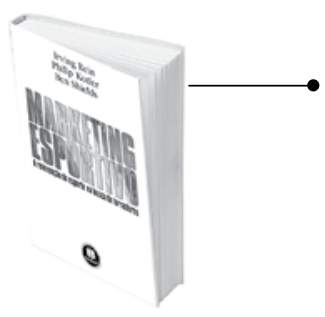

MARKETING ESPORTIVO: a reinvenção do esporte na busca de torcedores. Irving Rein; Philip Kotler; Ben Shields. São Paulo: Bookman, 2007. 360 p.

Esta obra trata de um dos mais importantes desafios da gestão esportiva: como conquistar e manter o fã, diante de um mercado cada vez mais competitivo e com novas modalidades disputando o mesmo espaço. Traduzido do original americano The Elusive Fan, Reinventing Sports in a Crowded Marketplace, é uma publicação importante por trazer Philip Kotler dentre seus autores, e também por abordar o futebol inglês, ao examinar o caso de sucesso do Manchester United. Dessa forma, não fica apenas nos exemplos do peculiar mercado esportivo americano.

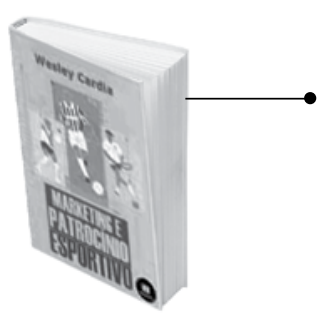

MARKETING E PATROCínIO ESPORTIVO. Wesley Cardia. São Paulo: Bookman, 2004. 262 p.

Wesley Cardia foi diretor de Marketing do Grêmio Foot-Ball Porto-Alegrense em meados dos anos 1990 e contabilizou alguns sucessos marcantes nas ações implantadas por lá. Seu livro ultrapassa a apresentação da teoria disponível, vai adiante, trazendo a prática para mostrar, por exemplo, como se monta um projeto de patrocínio e como fazer para definir preços. Traz ainda boas colocações sobre marketing de emboscada e exemplifica modelos de contratos. Útil para estudantes e profissionais da área.

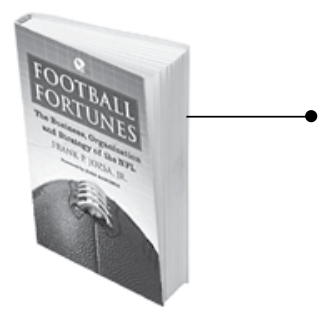

FOOTBALL FORTUNES: the business, organization and strategy of the NFL. Frank P. Jozsa, Jr.; John Maxymuck. Jefferson, NC: McFarland, 2010. 252 p.

Este livro é sobre o futebol da bola oval. Não é surpresa para ninguém que o futebol americano é um grande negócio, podendo trazer bons exemplos de práticas gerenciais para o futebol brasileiro. Para os estudiosos das possibilidades do futebol como negócio, é interessante um mergulho nas características da principal liga americana, a NFL (National Football League), sua expansão, fusões, realocações das cidades e a organização como franchising, bem como a importância econômica dos estádios para a saúde financeira dos clubes.

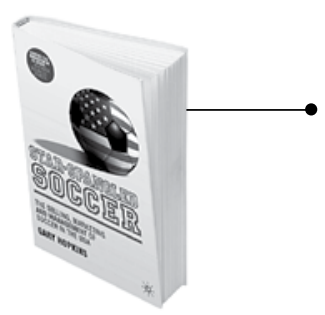

STAR-SPANGLED SOCCER: the selling, marketing and management of soccer in the USA. Gary Hopkins. New York: Palgrave MacMillan, 2010. 256 p.

Gary Hopkins tem 20 anos de atuação executiva no mercado do soccer americano e traz na obra a opinião de importantes tomadores de decisão. É livro interessante para compreender o esforço dos que lutam para tornar os EUA uma soccer nation. Com lançamento previsto para junho, este livro pretende mostrar como o futebol se desenvolveu nos EUA, especialmente depois que hospedou a Copa de 1994, responsável, segundo o autor, por uma corrente de eventos que fortaleceu a modalidade no país, candidato a hospedar em 2018 a Copa do Mundo de futebol masculino e, em 2020, a do feminino.

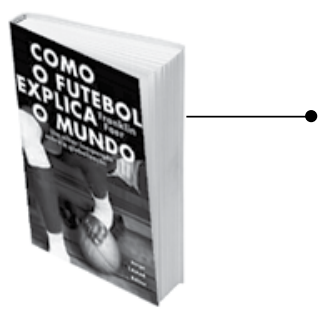

COMO 0 FUTEBOL EXPLICA 0 MUNDO: um olhar inesperado sobre a globalização. Franklin Foer. Rio de Janeiro: Zahar, 2005. 224 p.

- Franklin Foer escreve para a New Republic, conservadora revista política americana. Para realizar esse amplo trabalho de reportagem, viajou o mundo analisando o intercâmbio entre o futebol e a nova economia global. Esse aparente distanciamento faz bem à obra, que analisa o amálgama pancultural, social e econômico no qual está assentado o futebol. Visto como mais do que um esporte, é apresentado como capaz de impactar governos e lutas populares, com a paixão pelos clubes frequentemente superando até mesmo a devoção religiosa. 